Andreff, Wladimir. Is hosting the games enough to win? A predictive economic model of medal wins at 2014 winter olympics.

\title{
IS HOSTING THE GAMES ENOUGH TO WIN? A PREDICTIVE ECONOMIC MODEL OF MEDAL WINS AT 2014 WINTER OLYMPICS
}

\author{
WLADIMIR ANDREFF \\ Professeur émérite à l'Université de Paris 1 Panthéon Sorbonne \\ Président d'honneur de la International Association of Sport Economists et de la \\ European Sports Economics Associaition \\ Membre d'honneur de la European Association for Comparative Economic Studies, \\ ancien président de l'Association Française de Science Economique (2007-08).
}

Fecha recepción: junio de 2012

Fecha aceptación: octubre de 2012

JEL: L83.

\section{INTRODUCTION}

Soon after Russia has got the organisation of Winter Games in Sochi in 2014, official expectation, namely mentioned by President Vladimir Putin, has become that Russia will win the Games she is going to host. A same feeling has been reinforced by a high Olympic performance of China at Beijing Summer Games in 2008 since the host country has won the greatest number of gold medals and the second overall number of medals, compared to all other participating countries. Thus, it is legitimate to raise the question: is hosting the Games enough to win?

To the best of our knowledge nobody has attempted to elaborate on an economic model for predicting medal wins at Winter Olympics so far as it is confirmed by Forrest et al. (2012). This contrasts with Summer Olympics for which about thirty studies have estimated economic determinants of sporting performances. Namely, it has been empirically verified that the number of medals a country can make at Summer Olympics significantly depends on its population and GDP per inhabitant (Andreff, 2001). In the past decade, a number of papers have started providing economic predictions of medal distribution per country at next Olympic Games (Bernard, 2008; Bernard \& Busse, 2004; Hawksworth, 2008; Johnson \& Ali, 2004; Johnson \& Ali, 2008; Maennig \& Wellebrock, 2008; Wang \& Jiang, 2008). Our own model has exactly predicted $70 \%$, and correctly (with a small error margin), $88 \%$ of medal wins totals per nation at the 2008 Beijing Olympics (Andreff et al., 2008; Andreff, 2010). Although the dependent variable is the same - the number of medals won by each participating nation -, some independent variables have to be kept for Winter Games whereas some new variables must be introduced to capture the specificity of Winter Olympic sports. Thus, we would take stake of the good predictions achieved with our model for Summer Olympics to adapt it in view of forecasting the distribution of medal wins per nation at the 2014 Sochi Winter Games. 
Andreff, Wladimir. Is hosting the games enough to win? A predictive economic model of medal wins at 2014 winter olympics.

We start with briefly reminding the most interesting methodologies at work in estimating Summer Olympics medal distribution (1). Then we show how our own model has resolved the issue (2). The model has been used to predict medals totals per nation at the 2008 Olympics and prediction is compared to actual outcomes of different nations in Beijing, a comparison which is absolutely rare in the literature so far (3). A brief discussion provides justification for keeping some similar variables in a model attempting to estimate the determinants of medals distribution at Winter Olympics and to introduce some new variables that fit better with explaining winter sports performance; the discussion comes out with a somewhat different model (4). The latter is estimated with data about Winter Olympic Games from 1964 up to 2010 (5). The estimated model is then used to predict the medal distribution across participating nations at the 2014 Sochi Winter Olympics with a focus on the performance of host country (Russia) and CIS and Central and Eastern European countries - CEECs (6). A conclusion reminds the reader that all such predictions are to be taken with a pinch of salt (7).

\section{ECONOMIC DETERMINANTS OF OLYMPIC MEDALS}

A widespread assumption across sports economists is that a nation's Olympic performance must be determined by its endowment in economic and human resources and development of these resources. Thus, the starting point of most studies about economic determinants of Olympic medals consists in regressing a nation's medal wins total on its level of GDP per capita and population. Note that growth in medal wins by one country logically is an equivalent decrease in medals won by all other nations participating to the Olympics. Therefore, if one wants to understand the Olympic performance of one specific nation, account is to be taken of all other participating nations within the overall constraint of the allocated medals total during this year's Olympics.

In the first papers about economic determinants of Olympic performance, such as GDP per capita and population, these variables were combined with weather, nutrition, and mortality in the athlete's home nation. Later on, in various studies up to the 1970s, other variables had been considered as possible determinants of Olympic medal wins: protein consumption, religion, colonial past, newspapers supply, urban population, life expectancy, geographical surface area, military expenditures, judicial system and those sport disciplines taught at school. However, with the cold war period, another very significant variable emerged: a nation's political regime. The first Western work attempting to explain medal wins by the political regime of nations (Ball, 1972) immediately triggered a Soviet rejoinder (Novikov \& Maximenko, 1972), both differentiating capitalist and communist regimes. The first two econometric analyses of Olympic Games (Grimes et al., 1974; Levine, 1974) exhibited that communist countries were outliers in regressing medal wins on GDP per capita and population: they were winning more medals than their level of economic development and population were likely to predict. A last variable has been introduced, namely since Clarke (2000), which is the influence on medal wins of being the Olympics hosting country. The host gains more medals than otherwise due to big crowds of national fans, a stronger national athletes' motivation when competing on their home ground and being adapted to local weather, and not tired by a long pre-Games travel. More sophisticated econometric methodology has been used in recent articles that predicted Olympic medal wins, such as an ordered Logit model (Andreff, 2001), a 
Andreff, Wladimir. Is hosting the games enough to win? A predictive economic model of medal wins at 2014 winter olympics.

Probit model (Nevill et al., 2002) or an ordered Probit model (Johnson and Ali, 2004). The most often quoted reference is Bernard and Busse (2004) whose Tobit model has been assessed as the most performing one and then used by Jiang and $\mathrm{Xu}$ (2005), Pfau (2006) and others. Bernard and Busse's model is considered as the best achieved economic model for estimating and predicting Olympic performance ${ }^{1}$, in which two major independent variables do explain the great bulk of medal distribution across participating countries: GDP per capita and population. Three dummy variables capture a host country effect, the influence of belonging to Soviettype and other communist (and post-Soviet and post-communist after 1990) countries as against being a non communist market economy. Such dummies are supposed to capture the impact of political regime on medal wins.

\section{COUNTRIES' SPORT PERFORMANCES AT SUMMER OLYMPICS: ESTIMATION OF THEIR DETERMINANTS}

Starting from Bernard and Busse, we have elaborated on a more specified model (Andreff et al., 2008) with a few improving emendations. The dependent variable is the number of medal wins ${ }^{2}$ by each nation: $M_{i, t}$. Our first two explanatory variables are GDP per inhabitant in purchasing power parity dollars (PPP \$) and population. Both variables are four-year lagged $(t-4)$ under the assumption that four years are required to build up, train, prepare and make an Olympic team the most competitive in due time, four years later. That is, for explaining medal wins in 2008, we take 2004 GDP per capita and population as estimators. A Host dummy variable is used to capture a host country effect, i.e. the observed surplus of medals usually won by the national squad of hosting nation.

Our first emendation to Bernard and Busse's model regards the political regime variable: Bernard and Busse rather crudely divide the world into communist regimes and capitalist market economies which obviously fits with the cold war period. Since then, this is too crude when it comes to so-called post-communist transition economies (Andreff, 2004 \& 2007) in particular with regards to the sports economy sector which has differentiated a lot across former socialist countries during their institutional transformation process (Poupaux and Andreff, 2007). Such differentiation has translated into a scattered efficiency in winning Olympic medals after 1991 (Rathke \& Woitek, 2008).

Our classification distinguishes first Central Eastern European countries (CEEC) which gave up a Soviet-type centrally planned economy in 1989 or 1990, and transformed into a democratic political regime running a market economy: Bulgaria, the Czech Republic, Estonia, Hungary, Latvia, Lithuania, Poland, Romania, Slovakia (and Czechoslovakia until the 1993 split), Slovenia, and the GDR (until German reunification in 1990). Another commonality to this group is that these countries have all joined the European Union in 2004 or 2007. A second country group (TRANS) gathers new independent states (former Soviet republics) and some former CMEA member states which have started up a transition similar to the one in CEECs but are

\footnotetext{
${ }^{1}$ At least until the most recent publication by Forrest et al. (2012).

2 Bernard and Busse use the percentage of medal wins by each country $i$ for $M_{i, t}$ instead. Our regressions are calculated with both the absolute number of medals (Table 1) and the percentage of medals per country, and the results are not significantly different.

Papeles de Europa

25 (2012): 51-75
}

Doi: http://dx.doi.org/10.5209/rev_PADE.2012.n25.41095 
Andreff, Wladimir. Is hosting the games enough to win? A predictive economic model of medal wins at 2014 winter olympics.

lagging behind in terms of transformation into a democratic regime and some are stalling on the path toward a market economy: Armenia, Azerbaijan, Belarus, Georgia, Kazakhstan, Kyrgyzstan, Moldova, Mongolia, Russia, Tajikistan, Turkmenistan, Ukraine, Uzbekistan and Vietnam. None of them has joined the EU so far or has really an option to do so. The two next groups have not been Soviet regimes properly speaking in the past, although they have been both communist regimes and planned economies. In the first one (NSCOM), we sample those countries which have started up a transition process in the 1990s: Albania, BosniaHerzegovina, China, Croatia, Laos, Macedonia, Montenegro, and Serbia (and the former FSR Yugoslavia before the 1991 breakup). Two countries have not yet engaged into a democratic transformation and a market economy: Cuba and North Korea, and must be considered as still communist regimes (COM). All other countries are regarded as capitalist market economies $(C A P M E)$, the reference group in our estimations.

Then we have introduced a last variable that captures the influence on Olympic performance of a specific sporting culture in a region. For example, Afghan ladies are not used to have much sport participation or to attend sport shows, even less to be enrolled in the Olympic team. As a result of these cultural (sometimes institutional) disparities, some nations are more specialised in one specific sport discipline such as weight-lifting in Bulgaria, Turkey and Armenia, marathon and long distance runs in Ethiopia and Kenya, cycling in Belgium and the Netherlands, table tennis, judo and martial arts in Asia, sprint in Caribbean islands and the U.S., etc. It is not easy to design a variable that would exactly capture such regional sporting culture differences $^{3}$, but we have considered that regional dummies may reflect them. For model estimation, we divide the world into nine "sporting culture" regions: AFS, subSahara African countries; AFN: North African countries; NAM, North American countries; LSA, Latin and South American countries; EAST, Eastern European countries; WEU, Western European countries (taken as the reference region in our estimations); OCE, Oceania countries; MNE, Middle East countries; and ASI, (other) Asian countries.

Our first model is simply a specification à la Bernard and Busse, but with a differently defined political regime variable. Our estimation is based on a censored Tobit model since a non negligible number of countries that participate to the Olympics do not win any medal. Therefore, a zero value of the $M_{i, t}$ dependent variable does not mean that a country has not participated and we work out a simple Tobit, not a Tobit 2 (with a two stage Heckman procedure). Contrary to Bernard and Busse, we do not assume that preparing an Olympic team is timeless and, then, independent variables are fouryear lagged behind the dependent variable. Thus, GDP per inhabitant is noted $(Y / N)_{i, t-4}$, measured in 1995 PPP dollars, and $N_{i, t-4}$ stands for population. Dummies are introduced to test whether the Olympics year is significant, taking 2004 as reference. These dummies come out to be non significant. In a second model, we adopt a data panel Tobit to take into account unobserved heterogeneity, whose test

\footnotetext{
${ }^{3}$ Hoffmann et al. (2002) consider that an important determinant of Olympic successes lies in the degree to which sport and sporting activities are embedded in a nation's culture. The proxy used to capture such determinant is the total number of times a country has hosted Olympic Summer Games between 1946 and 1998. Our regional variable does not intend to capture only a nation's sporting culture but how much it is specific (different from the one of nations located in a different geographical area). 
Andreff, Wladimir. Is hosting the games enough to win? A predictive economic model of medal wins at 2014 winter olympics.

is significant ${ }^{4}$, and then we opt for an estimation with random effects. Our data ${ }^{5}$ encompass all Summer Olympics from 1976 to 2004, except 1980 and 1984 which are skipped out due to boycotts which have distorted the medal distribution per country. Our first specification (1) is:

$M_{i, t}^{*}=c+\alpha \ln N_{i, t-4}+\beta \ln \left(\frac{Y}{N}\right)_{i, t-4}+\gamma$ Host $_{i, t}+\sum_{p} \delta_{p}$ Political Regime $_{p, i}+\sum_{q} \kappa_{q}$ Year $_{q, i}+\varepsilon_{i, t}$

where $\varepsilon_{i, t} \sim N\left(0, \sigma^{2}\right)$

$M_{i, t}$ observation is defined by $M_{i, t}=\left\{\begin{array}{ccc}M_{i, t}^{*} \text { if } & M_{i, t}^{*}>0 \\ 0 & \text { if } & M_{i, t}^{*} \leq 0\end{array}\right.$

Our second specification (2) is an emended variant of Bernard and Busse model, including our more specific political regime variable, but also above-described dummies standing for regions of sporting culture (Region $\left.{ }_{r, i}\right)$ :

$$
\begin{aligned}
M_{i, t}^{*}=c+ & \alpha \ln N_{i, t-4}+\beta \ln \left(\frac{Y}{N}\right)_{i, t-4}+\gamma \text { Host }_{i, t}+\sum_{p} \delta_{p} \text { Political Regime }_{p, i} \\
& +\sum_{r} \rho_{r} \text { Regions }_{r, i}+u_{i}+\varepsilon_{i, t}
\end{aligned}
$$

where $\varepsilon_{i, t} \sim N\left(0, \sigma_{\varepsilon}^{2}\right)$ and $u_{i} \sim N\left(0, \sigma^{2}{ }_{u}\right)$

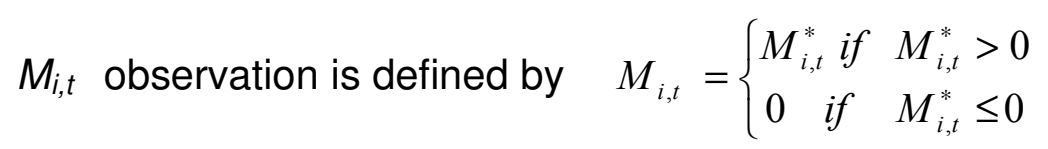

In a third specification (3), the one used for prediction, we have introduced an additional variable $M_{i, t-4}$ on the right-hand side of model (2), just like Bernard and Busse who do not comment why they proceed in such a way. Our idea is that winning medals at the previous Olympics matters for an Olympic national team which usually expects and attempts to achieve at least as well as four years ago. Such inertial effect is all the more relevant for a nation eager to win as many medals as possible from one Olympiad to the other (a national 'Olympics cult' ${ }^{\text {' }}$ ) and mobilise a lot of resources to succeed in. The resulting inertia differentiates those nations pulled by Olympics cult from those nations which are used to win zero or few medals. These two groups must be distinguished with using $M_{i, t-4}$ otherwise the prediction will be distorted.

\footnotetext{
${ }^{4} \mathrm{~A}$ test of maximum likelihood shows that the rho coefficient is significant $(\operatorname{Pr}=0.00)$.

${ }^{5}$ Our data panel is not balanced since the number of existing countries in the world has increased between 1976 and 2004, namely due to the breakup of the former Soviet Union, former Yugoslavia and former Czechoslovakia (+ 20 countries), only partly compensated by the re-unification of Germany and Yemen (- 2 countries).

${ }^{6}$ Which has been fuelled in particular by the cold war, but it has not vanished yet in a number of countries.

Papeles de Europa 
Andreff, Wladimir. Is hosting the games enough to win? A predictive economic model of medal wins at 2014 winter olympics.

All our estimations deliver significant results (Table 1). In the first estimation, all coefficients are positive and significant at a $1 \%$ threshold, except for year dummies. Thus, it is once again confirmed that medal wins are determined by GDP per capita, population and a host country effect. Political regime is also an explanatory variable, in particular in the case of communist and post-communist transition countries. Our second estimation (Tobit/panel) all in all exhibits the same results. The coefficients of regional sporting culture are significant except for Latin America, an area in which the North American sporting culture may have permeated namely through Caribbean countries and Mexico (classified in NAM).

Table 1 - Tobit estimation of medal wins at Summer Olympics

\begin{tabular}{|c|c|c|c|}
\hline Independent variables & Tobit Model 1 & $\begin{array}{c}\text { Tobit (panel) } \\
\text { Model } 2\end{array}$ & $\begin{array}{l}\text { Tobit Model } 3 \\
\text { with lagged } M\end{array}$ \\
\hline Log population (t-4) & $9,14^{* \star *}$ & $4,15^{\star \star *}$ & $2,15^{\star \star *}$ \\
\hline Log GDP per capita (t-4) & $12,42^{* * *}$ & $5,44^{\star \star *}$ & $2,73^{* \star \star}$ \\
\hline Host & $24,37^{\star * *}$ & $10,40^{* * *}$ & $10,04^{* * *}$ \\
\hline \multicolumn{4}{|l|}{ Political Regime (ref. CAPME) } \\
\hline COM & $24,34^{* * *}$ & $11,18^{* * *}$ & $5,76^{* *}$ \\
\hline TRANS & $23,24^{\star * *}$ & $20,97^{\star * \star}$ & $8,15^{\star * \star}$ \\
\hline CEEC & $21,43^{* * *}$ & $17,94^{* * *}$ & $6,71^{* *}$ \\
\hline NSCOM & $11,98^{* * *}$ & $8,06^{* * *}$ & $5,22^{*}$ \\
\hline \multicolumn{4}{|l|}{ Region (ref. WEU) } \\
\hline AFN & & $-4,45^{*}$ & $-1,81$ \\
\hline AFS & & $3,67^{*}$ & 0,75 \\
\hline NAM & & $7,93^{* * *}$ & 0,076 \\
\hline LSA & & 0,57 & $-1,08$ \\
\hline ASI & & $-4,34^{* \star *}$ & $-2,58^{*}$ \\
\hline EAST & & $-5,53^{*}$ & $-3,5$ \\
\hline MNE & & $-5,00^{* \star *}$ & $-2,47^{*}$ \\
\hline OCE & & $6,277^{* *}$ & 1,3 \\
\hline \multicolumn{4}{|l|}{ Year dummy (ref. 2004) } \\
\hline 1976 & 4,63 & & \\
\hline 1988 & $-0,2$ & & \\
\hline 1992 & 3,33 & & \\
\hline 1996 & 3,35 & & \\
\hline 2000 & 0,31 & & \\
\hline Medals (t-4) & & & $0,95^{* * *}$ \\
\hline Constant & $-138^{\star * \star}$ & $'-51,30^{\star \star \star}$ & $-31,57^{\star \star \star}$ \\
\hline Number of observations & 941 & 941 & 831 \\
\hline Log-likelihood value & $-1646,1$ & $-1551,5$ & $-1224,2$ \\
\hline Pseudo R2 & 0,17 & 0,19 & 0,34 \\
\hline
\end{tabular}

*** Significant at $1 \%$ threshold; ${ }^{* *}$ at $5 \% ;{ }^{*}$ at $10 \%$.

Source: Andreff et al., 2008.

Since Western Europe is the reference a significant coefficient with a positive sign means that a region performs relatively better than Western Europe in terms of Olympic medals (a negative sign means a lower relative performance than Western 
Andreff, Wladimir. Is hosting the games enough to win? A predictive economic model of medal wins at 2014 winter olympics.

Europe). Sub-Sahara Africa, North America and Oceania perform better. It is a little bit surprising for Sub-Sahara African countries since they are among the least developed countries in the world (except South Africa), but such effect is due to a few African countries which are extremely specialised in one sport discipline where they are capable to win a non negligible number of medals, such as Ethiopia and Kenya in long distance runs. With negative coefficients, North Africa, Asia, Eastern Europe and Middle East show a lower relative performance than Western Europe. It is not surprising for North Africa and the Middle East due to some restrictions to sporting culture in various countries. In the case of Asia, only few countries are capable to win a significant number of medals (China, both Koreas, Mongolia) given their GDP per capita. A surprise is a negative coefficient for Eastern European countries which are known as outliers or over-performers (given their GDP per capita and population). In fact, the negative coefficient results from Political Regime variable which already captures their over-performance.

\section{PREDICTING MEDAL WINS AT BEIJING OLYMPICS: COMPARISON WITH OBSERVED OUTCOMES}

Then, our model (3) is used to predict medal distribution at the 2008 Beijing Olympics:

$$
\begin{aligned}
M_{i, t}^{*}=c & +\alpha \ln N_{i, t-4}+\beta \ln \left(\frac{Y}{N}\right)_{i, t-4}+\gamma \text { Host }_{i, t}+\sum_{p} \delta_{p} \text { Political Regime }_{p, i}+\sum_{r} \rho_{r} \text { Regions }_{r, i} \\
& +\theta M_{i, t-4}+\varepsilon_{i, t}
\end{aligned}
$$

where $\varepsilon_{i, t} \sim N\left(0, \sigma^{2}\right)$

$M_{i, t}$ observation is defined by $M_{i, t}=\left\{\begin{array}{ccc}M_{i, t}^{*} \text { if } & M_{i, t}^{*}>0 \\ 0 \text { if } & M_{i, t}^{*} \leq 0\end{array}\right.$

Since we use here a pooling estimation ${ }^{7}$ of Model 3, it may suffer from an endogeneity bias and the results may be biased by a correlation between the lagged endogenous variable and the error term. We have treated this issue with a dynamic panel GMM (Arellano \& Bond, 1991). This technique provides estimated coefficients and predictions that are robust and close to those estimated with a Tobit model. Our predictions are published (Andreff et al., 2008) only for a sub-sample of countries gathered in Table 2.

The first-ranked predicted winner is, as usual, the U.S., followed by Russia and China, which benefits from a host country effect. Most developed and democratic market economies (CAPME) are predicted to be among the major medal winners together with some pot-communist transition countries. Our forecast for France was between 35 and 38 medals while the State Secretary for Sports was hoping that the national team would reach 40 .

\footnotetext{
${ }^{7}$ A test of maximum likelihood shows that the rho coefficient is not significant $(\operatorname{Pr}=0.26)$ which allows to choose a pooling estimation.

Papeles de Europa 
Andreff, Wladimir. Is hosting the games enough to win? A predictive economic model of medal wins at 2014 winter olympics.

Table 2 - Prediction of medal wins at Beijing Olympics

\begin{tabular}{|c|c|c|c|c|}
\hline & $\begin{array}{l}\text { Medals won in } \\
2004\end{array}$ & $\begin{array}{c}\text { Médial wins } \\
\text { predicted in } 2008\end{array}$ & Lower bound & Upper bound \\
\hline \multicolumn{5}{|l|}{ CEEC: } \\
\hline Bulgaria & 12 & 12 & 10 & 13 \\
\hline Hungary & 17 & 19 & 17 & 21 \\
\hline Poland & 10 & 14 & 12 & 16 \\
\hline Czech Republic & 8 & 10 & 8 & 12 \\
\hline Romania & 19 & 21 & 19 & 23 \\
\hline \multicolumn{5}{|l|}{ TRANS: } \\
\hline Belarus & 15 & 17 & 14 & 20 \\
\hline Kazakhstan & 8 & 11 & 8 & 14 \\
\hline Russia & 92 & 96 & 93 & 100 \\
\hline Ukraine & 23 & 27 & 24 & 29 \\
\hline \multicolumn{5}{|l|}{ NSCOM } \\
\hline China & 63 & 80 & 73 & 86 \\
\hline Cuba & 27 & 29 & 25 & 33 \\
\hline \multicolumn{5}{|l|}{ CAPME: } \\
\hline Germany & 49 & 52 & 50 & 54 \\
\hline Australia & 49 & 51 & 47 & 54 \\
\hline Canada & 12 & 15 & 13 & 18 \\
\hline United States & 102 & 106 & 103 & 110 \\
\hline France & 33 & 36 & 35 & 38 \\
\hline Great Britain & 30 & 47 & 32 & 35 \\
\hline Italy & 32 & 35 & 34 & 36 \\
\hline \multicolumn{5}{|c|}{ Less developed countries } \\
\hline Brazil & 10 & 12 & 10 & 14 \\
\hline South Korea & 30 & 30 & 27 & 32 \\
\hline Kenya & 7 & 2 & 1 & 4 \\
\hline Jamaica & 5 & 11 & 0 & 4 \\
\hline Turkey & 10 & 9 & 7 & 11 \\
\hline
\end{tabular}

Source: Andreff et al., 2008.

The publication of our article in French (Andreff et al., 2008) one month before the opening of Beijing Olympics rapidly became a hit in different French and European media and TV channels. First interviews asked to focus on our prediction. In a second wave, after the Games end, all interviewers became eager to know for which countries the model had provided correct or wrong prediction and, in the latter case, why were it so. This triggered the writing of a follow up companion paper requested by the French National Institute for Sport and Physical Education (INSEP) to be included in its volume devoted to the overall outcome of Beijing Olympics for France (Andreff, 2009).

Our model provided good predictions regarding those 189 countries for which data were available and computable: $70 \%$ of the observed results belong to our predicted confidence interval. If one assesses our model prediction as acceptable when its 
Andreff, Wladimir. Is hosting the games enough to win? A predictive economic model of medal wins at 2014 winter olympics.

error margin is not bigger than a two-medal difference between prevision and reality, then it correctly predicts $88 \%$ of all Beijing results. The remaining unexplained $12 \%$ (23 nations) account for sporting "surprises" - unexpected results. The model correctly predicts the first ten medal winners, except Japan (instead of Ukraine), misses only four out of the first twenty winners, although with a slightly different ranking. However, the most interesting results are witnessed when the model is clearly wrong in its prediction that basically happens for 23 countries, because it means that our five variables (plus the inertial variable) have not captured some core explanation of the Olympics outcome. Fortunately, economists are not capable to predict all the detailed Olympics results, otherwise why still convene the Games?

Which are the major "surprises" delivered by actual results when compared with our predictions? The first one is a quite bigger than expected medal wins by the Chinese team - all published predictions have been wrong in this respect. Our model has clearly underestimated the host country effect in China. Possibly, Chinese performance has also been boosted by some undetected doping ${ }^{8}$. The second surprise is the underperformance of the Russian Olympic team, the worst since the cold war. It was regarded so much "catastrophic" that Mr. Putin convened the highest decision makers of Russian sport to command a new Olympic policy likely to avoid a repeated disaster at the 2012 London Olympics. In the same vein, some other transition countries, namely Romania, have won fewer medals than expected in Beijing. The current state of reforming institutions and restructuring the whole sports sector in these countries (Poupaux and Andreff, 2007) has not been sufficiently captured in our model, despite our more refined political regime variable.

The last three significant surprises are Great Britain, Jamaica and Kenya, the latter being the only two developing countries ranked among the first twenty medal winners. Early preparation of a super-competitive team for the 2012 London Olympics may have been the cause for higher than expected outcomes of the British team, as it is suggested by Maennig and Wellebrock (2008) who have introduced a "next Olympics host country" variable in their prediction. However, such future host country effect slightly improves the authors' forecast: 38 predicted medals as against 47 won by Great Britain. Without such effect our own model predicted between 32 and 35 medals for Great Britain. British medals concentration in cycling (12 medals) may trace back again to undetected doping and/or deep specialisation of a nation in one sport discipline. The latter is the most likely explanation for Jamaican medals ${ }^{9}$ concentrated in sprint and Kenyan medals in long distance runs. Though we have taken into account such specialisation through our lagged $M_{i, t-4}$ variable - Kenya had won 7 medals and Jamaica 5 in the same disciplines at Athens Olympics -, the inertia captured with this variable reveals to be insufficient.

\footnotetext{
${ }^{8}$ This issue is discussed in depth in Andreff et al. (2008) explaining why we had not been able to integrate doping among independent variables despite the fact that we wished to do so.

${ }^{9}$ Some Jamaican sprint finalists have been controlled positive in doping tests during the weeks after the Beijing Games, which may be another explanatory variable.

Papeles de Europa

25 (2012): 51-75
}

Doi: http://dx.doi.org/10.5209/rev_PADE.2012.n25.41095 
Andreff, Wladimir. Is hosting the games enough to win? A predictive economic model of medal wins at 2014 winter olympics.

\section{A MODEL ADAPTED TO ESTIMATING THE DETERMINANTS OF MEDAL WINS AT WINTER OLYMPICS}

The context of Winter Olympics is rather different from the one of Summer Olympics. In 1976, 92 countries had participated to Summer Olympics with 6,084 athletes while they were only 37 countries participating to Winter Olympics the same year, with 1,123 athletes (Table 3). In 2004, 201 countries were participating to Athens Olympics with 10,658 athletes whereas 80 countries had participated to the 2006 Winter Games in Turin with 2,651 athletes. From a global economic standpoint, Winter Olympics is a rather small sports mega-event compared to Summer Olympic Games. However, the former has grown a lot during the span of time covered in this paper. The number of participating countries has increased from 36 in 1964 up to 82 in 2010 while the number of athletes has augmented from 1,091 to 2,629. The number of medals to be won at Winter Olympics is smaller than the one observed at Summer Olympic Games (over 900 overall since 2000): it has grown from 103 in 1964 up to 258 in 2010. When it comes to the number of nations having won at least one Olympic medal, it has increased from 14 in 1964 to 26 in 2010 (as against a maximum of 80 countries at the 2000 Summer Games).

Table 3 - Winter Olympic performances, 1964-2010

\begin{tabular}{|lc|cccc|}
\hline City & Year & $\begin{array}{c}\text { Participating } \\
\text { countries }\end{array}$ & $\begin{array}{c}\text { Countries } \\
\text { with } \mathrm{M}>0\end{array}$ & $\begin{array}{c}\text { Overall number } \\
\text { of medals }\end{array}$ & $\begin{array}{c}\text { Participating } \\
\text { athletes }\end{array}$ \\
\hline Innsbruck & 1964 & 36 & 14 & 103 & 1091 \\
Grenoble & 1968 & 37 & 15 & 106 & 1171 \\
Sapporo & 1972 & 35 & 17 & 105 & 1008 \\
Innsbruck & 1976 & 37 & 16 & 111 & 1123 \\
Lake Placid & 1980 & 37 & 19 & 115 & 1072 \\
Sarajevo & 1984 & 48 & 17 & 117 & 1279 \\
Calgary & 1988 & 57 & 17 & 138 & 1424 \\
Albertville & 1992 & 63 & 20 & 171 & 1772 \\
Lillehammer & 1994 & 67 & 22 & 183 & 1747 \\
Nagano & 1998 & 72 & 24 & 205 & 2176 \\
Salt Lake City & 2002 & 77 & 24 & 234 & 2386 \\
Turin & 2006 & 80 & 26 & 252 & 2651 \\
Vancouver & 2010 & 82 & 26 & 258 & 2629 \\
\hline
\end{tabular}

Source: IOC.

Since population, GDP per inhabitant and the host country dummy variable have emerged as basic determinants of medal wins at Summer Olympics, we keep them in the Winter Olympics model. Keeping GDP per capita in the model is particularly sensible because it is nearly obvious from Table 4 that there is a relationship between the number of medal wins and the level of economic development. In Table 4, country groups are those defined by the World Bank. Developed market economies (DMEs) are countries with a GDP per inhabitant over 10,725\$ in 2006; (newly) emerging economies (NMEs) are countries whose GDP per inhabitant is between 3,466 $\$$ and 10,725\$; intermediary income (developing) countries (IICs) are those with a GDP per inhabitant between $876 \$$ and $3,465 \$$; least developed countries (LDCs) are those with a GDP per inhabitant below 876\$. At Winter Olympic 
Andreff, Wladimir. Is hosting the games enough to win? A predictive economic model of medal wins at 2014 winter olympics.

Games, one witness a concentration of medal wins on DMEs whatever the number of participating DMEs. The average number of medal wins is always higher in the DME and NME groups than in IICs and LDCs. Even with a growing number of participating countries - from 4 in 1964 to 20 in 2010 for IICs and from 3 to 13 for LDCs - these two country groups are not able to substantially increase their share in the medals total. In most Winter Games, LDCs have not won even a medal (except in 1992 and 1994 with just one medal win).

Table 4 - Uneven medal distribution at Winter Olympics by level of economic development

\begin{tabular}{|c|c|c|c|c|c|c|}
\hline Year & $\begin{array}{l}\text { Country } \\
\text { group }\end{array}$ & $\begin{array}{c}\text { Number of } \\
\text { medals }\end{array}$ & Mean: m & $\begin{array}{l}\text { Coefficient of } \\
\text { variation: } \mathrm{s} / \mathrm{m}\end{array}$ & $\begin{array}{l}\text { Number of } \\
\text { countries }\end{array}$ & $\begin{array}{l}\text { Countries } \\
\text { with } M>0\end{array}$ \\
\hline \multirow[t]{4}{*}{1964} & DME & 77 & 3.67 & 1.27 & 21 & 12 \\
\hline & NEC & 26 & 3.25 & 2.71 & 8 & 2 \\
\hline & IIC & 0 & 0 & 0.00 & 4 & 0 \\
\hline & LDC & 0 & 0 & 0.00 & 3 & 0 \\
\hline \multirow[t]{4}{*}{1968} & DME & 83 & 3,95 & 1.13 & 21 & 11 \\
\hline & NEC & 23 & 2,56 & 1.70 & 9 & 4 \\
\hline & $\mathrm{IIC}$ & 0 & 0 & 0.00 & 5 & 0 \\
\hline & LDC & 0 & 0 & 0.00 & 2 & 0 \\
\hline \multirow[t]{4}{*}{1972} & DME & 71 & 3,38 & 1.12 & 21 & 13 \\
\hline & NEC & 34 & 4,25 & 1.58 & 8 & 4 \\
\hline & IIC & 0 & 0 & 0.00 & 4 & 0 \\
\hline & LDC & 0 & 0 & 0.00 & 2 & 0 \\
\hline \multirow[t]{4}{*}{1976} & DME & 64 & 2,67 & 1.26 & 24 & 13 \\
\hline & NEC & 47 & 5,22 & 1.97 & 9 & 3 \\
\hline & IIC & 0 & 0 & 0.00 & 4 & 0 \\
\hline & LDC & 0 & 0 & 0.00 & 0 & 0 \\
\hline \multirow[t]{4}{*}{1980} & DME & 67 & 2,91 & 1.24 & 23 & 14 \\
\hline & NEC & 47 & 5,22 & 1.88 & 9 & 4 \\
\hline & IIC & 1 & 0,25 & 2.00 & 4 & 1 \\
\hline & LDC & 0 & 0 & 0.00 & 1 & 0 \\
\hline \multirow[t]{4}{*}{1984} & DME & 61 & 2,26 & 1.54 & 27 & 13 \\
\hline & NEC & 55 & 5 & 1.96 & 11 & 3 \\
\hline & IIC & 1 & 0,17 & 2.41 & 6 & 1 \\
\hline & LDC & 0 & 0 & 0.00 & 4 & 0 \\
\hline \multirow[t]{4}{*}{1988} & DME & 78 & 2,44 & 1.56 & 32 & 13 \\
\hline & NEC & 57 & 5,18 & 2.10 & 11 & 3 \\
\hline & IIC & 3 & 0,3 & 3.17 & 10 & 1 \\
\hline & LDC & 0 & 0 & 0.00 & 4 & 0 \\
\hline \multirow[t]{4}{*}{1992} & DME & 141 & 4,41 & 1.58 & 32 & 16 \\
\hline & NEC & 26 & 1,86 & 3.30 & 14 & 2 \\
\hline & IIC & 3 & 0,25 & 3.48 & 12 & 1 \\
\hline & LDC & 1 & 0,2 & 2.25 & 5 & 1 \\
\hline 1994 & DME & 149 & 4,52 & 1.58 & 33 & 16 \\
\hline
\end{tabular}

Papeles de Europa 
Andreff, Wladimir. Is hosting the games enough to win? A predictive economic model of medal wins at 2014 winter olympics.

\begin{tabular}{|c|c|c|c|c|c|c|}
\hline & NEC & 23 & 1,44 & 3.99 & 16 & 1 \\
\hline & IIC & 10 & 1,67 & 0.76 & 12 & 4 \\
\hline & LDC & 1 & 0,83 & 0.49 & 6 & 1 \\
\hline \multirow[t]{4}{*}{1998} & DME & 170 & 5,15 & 1.50 & 33 & 17 \\
\hline & NEC & 21 & 1,4 & 3.33 & 15 & 2 \\
\hline & IIC & 14 & 0,67 & 3.03 & 16 & 5 \\
\hline & LDC & 0 & 0 & 0.00 & 8 & 0 \\
\hline \multirow[t]{4}{*}{2002} & DME & 197 & 5,97 & 1.64 & 33 & 16 \\
\hline & NEC & 25 & 1,47 & 2.22 & 17 & 5 \\
\hline & IIC & 12 & 0,67 & 2.94 & 18 & 3 \\
\hline & LDC & 0 & 0 & 0.00 & 9 & 0 \\
\hline \multirow[t]{4}{*}{2006} & DME & 201 & 5,74 & 1.54 & 35 & 15 \\
\hline & NEC & 36 & 2,4 & 2.33 & 15 & 7 \\
\hline & IIC & 15 & 0,83 & 3.13 & 18 & 4 \\
\hline & LDC & 0 & 0 & 0.00 & 12 & 0 \\
\hline \multirow[t]{4}{*}{2010} & DME & 207 & 6,09 & 1.60 & 34 & 16 \\
\hline & NEC & 36 & 2,4 & 1,70 & 15 & 7 \\
\hline & IIC & 15 & 0,75 & 3.35 & 20 & 3 \\
\hline & LDC & 0 & 0 & 0.00 & 13 & 0 \\
\hline
\end{tabular}

s: standard deviation; M: number of medals per country

Although, at first sight, the political regime seems to be less relevant as a variable that differentiates among the Winter Games' medal winners, we have kept it in the model with some slight emendation compared to the Summer Olympics model. The reference country group remains CAPME for capitalist market economies; CEECs are those post-communist economies which have joined the EU in either 2004 or 2007; and we have gathered all the remaining post-communist economies in an EXCOM country group even though it would be sensible to consider Cuba and North Korea as still communist regimes (but their performance at Winter Games is negligible or nil).

It seems that a political regime variable might be a significant determinant (to be tested) of medal distribution per nation at Winter Olympics as well (Table 5). Being a centrally planned economy with some sort of communist regime was an advantage to win Winter Olympics medals until 1988 (and from 1972 to 1988 for CEECs). The average number of medal wins was higher in the EXCOM group than in the CEEC group and the latter higher than in the CAPME reference group during this span of time, even though medals were concentrated on a small number of communist countries, namely the former USSR. The collapse of the communist regime has had a seemingly significant impact on the number of medal wins which dramatically dropped in CEECs after 1990; it dropped much less significantly in other former communist countries, namely in the former USSR, and recovered as soon as 1994 while the recovery in medal wins happened only in 2010 in CEECs. Such difference in momentum is probably due to harsher shock of economic transition, deeper and swifter transformation of the state-run sport system into a market sport economy in CEECs as compared with other post-communist countries, including Russia (Poupaux \& Andreff, 2007). 
Andreff, Wladimir. Is hosting the games enough to win? A predictive economic model of medal wins at 2014 winter olympics.

Table 5 - Uneven medal distribution at Winter Olympics by political regime

\begin{tabular}{|c|c|c|c|c|c|c|}
\hline Year & $\begin{array}{l}\text { Country } \\
\text { group }\end{array}$ & $\begin{array}{c}\text { Number of } \\
\text { medals }\end{array}$ & Mean: $m$ & $\begin{array}{l}\text { Coefficient of } \\
\text { variation: } \mathrm{s} / \mathrm{m}\end{array}$ & $\begin{array}{c}\text { Number of } \\
\text { countries }\end{array}$ & $\begin{array}{l}\text { Countries } \\
\text { with } M>0\end{array}$ \\
\hline \multirow[t]{3}{*}{1964} & CAPME & 77 & 2,85 & 1.53 & 27 & 12 \\
\hline & CEEC & 1 & 0,2 & 2.25 & 5 & 1 \\
\hline & EXCOM & 25 & 6,25 & 2.00 & 4 & 1 \\
\hline \multirow[t]{3}{*}{1968} & CAPME & 83 & 2,96 & 1.43 & 28 & 11 \\
\hline & CEEC & 10 & 1,67 & 1.35 & 6 & 3 \\
\hline & EXCOM & 13 & 4,33 & 1.73 & 3 & 1 \\
\hline \multirow[t]{3}{*}{1972} & CAPME & 71 & 2,84 & 1.29 & 25 & 13 \\
\hline & CEEC & 18 & 3 & 1.84 & 6 & 3 \\
\hline & EXCOM & 16 & 4 & 2.00 & 4 & 1 \\
\hline \multirow[t]{3}{*}{1976} & CAPME & 64 & 2,21 & 1.45 & 29 & 13 \\
\hline & CEEC & 20 & 3,33 & 2.31 & 6 & 2 \\
\hline & EXCOM & 27 & 13,5 & 1.41 & 2 & 1 \\
\hline \multirow[t]{3}{*}{1980} & CAPME & 67 & 2,48 & 1.41 & 27 & 14 \\
\hline & CEEC & 26 & 4,33 & 2.12 & 6 & 4 \\
\hline & EXCOM & 22 & 5,5 & 2.00 & 4 & 1 \\
\hline \multirow[t]{3}{*}{1984} & CAPME & 61 & 1,65 & 1.90 & 37 & 13 \\
\hline & CEEC & 30 & 5 & 1.92 & 6 & 2 \\
\hline & EXCOM & 26 & 5,2 & 2.13 & 5 & 2 \\
\hline \multirow[t]{3}{*}{1988} & CAPME & 78 & 1,7 & 1.98 & 46 & 13 \\
\hline & CEEC & 28 & 4,67 & 2.15 & 6 & 2 \\
\hline & EXCOM & 32 & 6,4 & 1.98 & 5 & 2 \\
\hline \multirow[t]{3}{*}{1992} & CAPME & 141 & 2,88 & 2.08 & 49 & 16 \\
\hline & CEEC & 3 & 0,38 & 2.79 & 8 & 1 \\
\hline & EXCOM & 27 & 4,5 & 2.03 & 6 & 3 \\
\hline \multirow[t]{3}{*}{1994} & CAPME & 146 & 3,32 & 1.96 & 44 & 15 \\
\hline & CEEC & 3 & 0,3 & 3.17 & 10 & 1 \\
\hline & EXCOM & 34 & 2,62 & 2.38 & 13 & 6 \\
\hline \multirow[t]{3}{*}{1998} & CAPME & 170 & 3,78 & 1.84 & 45 & 17 \\
\hline & CEEC & 4 & 0,4 & 2.43 & 10 & 2 \\
\hline & EXCOM & 31 & 1,82 & 2.53 & 17 & 5 \\
\hline \multirow[t]{3}{*}{2002} & CAPME & 196 & 3,92 & 2.15 & 50 & 15 \\
\hline & CEEC & 12 & 1,2 & 1.17 & 10 & 5 \\
\hline & EXCOM & 26 & 1,53 & 2.37 & 17 & 4 \\
\hline \multirow[t]{3}{*}{2006} & CAPME & 201 & 3,94 & 1.97 & 51 & 15 \\
\hline & CEEC & 12 & 1,2 & 1.17 & 10 & 6 \\
\hline & EXCOM & 39 & 2,05 & 2.67 & 19 & 5 \\
\hline \multirow[t]{3}{*}{2010} & CAPME & 204 & 3,92 & 2.14 & 52 & 15 \\
\hline & CEEC & 21 & 2,1 & 1.13 & 10 & 6 \\
\hline & EXCOM & 33 & 1,65 & 2.45 & 20 & 5 \\
\hline
\end{tabular}

s: standard deviation; M: number of medals per country 
Andreff, Wladimir. Is hosting the games enough to win? A predictive economic model of medal wins at 2014 winter olympics.

With regards to the Regions dummy variable supposed to capture differences in sporting culture, we do not expect that it must be as much significant for Winter Olympics as it has been tested for Summer Olympics. The reason is very simple: all those countries which participate to Winter Games have in common a sporting culture geared towards the practice of winter sports wherever they are located and whatever their overall sporting culture. This is confirmed by the fact that, contrary to Summer Olympics, many countries in the world do not participate to Winter Olympics. Thus, we skip the regional dummy out of the Winter Olympics model.

Now if a country would like to develop a wide range of winter sports on its territory, making it able to train and select performing athletes, it could not significantly achieve it without some proper weather conditions, in particular enough snow coverage per year, and more than a minimal endowment in winter sports resorts and facilities ${ }^{10}$. This leads us to introduce two new variables in the model. The first one Snow is a dummy variable differentiating countries with regards to their average degree of annual snow coverage. Indeed, among those countries which have participated at least once to Winter Olympics, the degree of snow coverage is quite variable, but it was not easy to get a precise measure of snow coverage back to 1964. Thus we have gathered information provided by Maps of the World and the World Meteorological Organisation regarding the main climates, precipitations and temperature in order to build up the Snow dummy. The outcome in our sample of participating countries ${ }^{11}$ is as follows:

- POL (a so-called "polar" coverage for countries with a long duration of annual snow coverage): Belarus, Canada, Estonia, Finland, Iceland, Latvia, Lithuania, Mongolia, Nepal, Norway, Russia (by extension CIS and the former USSR), Sweden = 12 countries;

- $\quad H I G H$ (local high winter snow coverage in otherwise temperate climate countries): Austria, Chile, Croatia, Czech Republic (by extension former Czechoslovakia), Denmark, France, Germany (by extension former GDR), Italy, Japan, Kyrgyzstan, Poland, Slovakia, Slovenia, Spain, Switzerland, Tajikistan, USA (and by extension former Yugoslavia) = 17 countries;

- MIDDLE (local middle snow coverage in temperate climate countries): Albania, American Samoa, Argentina, Armenia, Australia, Azerbaijan, Belgium, Bolivia, Bosnia-Herzegovina, Bulgaria, China (including Hong Kong), Cyprus, Fiji, Georgia, Great Britain, Greece, Guam, Hungary, Ireland, Israel, Lebanon, Luxembourg, Macedonia, Moldova, Netherlands, New Zealand, North Korea, Portugal, Peru, Romania, Serbia, South Africa, South Korea, Swaziland, Taiwan, Turkey, Ukraine, Uruguay = 39 countries;

- LOW (countries with no or low snow coverage): Algeria, Bermuda, Brazil, Cameroon, Colombia, Costa Rica, Ethiopia, Ghana, Guatemala, Honduras, India, Iran, Jamaica, Kazakhstan, Kenya, Madagascar, Mexico, Morocco, Netherlands Antilles, Pakistan, Philippines, Senegal, Thailand, Trinidad \& Tobago, Uzbekistan, Venezuela, Virgin Islands $=27$ countries.

\footnotetext{
${ }^{10}$ Thus we neglect some exceptions as Dubai with its ski resort in a country without any natural snow coverage and without even a second winter sports facility in the country.

${ }^{11}$ Some countries which have participated to Winter Olympics are excluded from our ample since data about population and GDP cannot be traced back to 1964. They are: Andorra, Caiman Islands, Liechtenstein, Monaco, Montenegro, Porto Rico, and San Marino. No big medal winner.

Papeles de Europa

25 (2012): 51-75

Doi: http://dx.doi.org/10.5209/rev_PADE.2012.n25.41095 
Andreff, Wladimir. Is hosting the games enough to win? A predictive economic model of medal wins at 2014 winter olympics.

Table 6 - Uneven medal distribution at Winter Olympics by level of snow coverage

\begin{tabular}{|c|c|c|c|c|c|c|}
\hline Year & $\begin{array}{l}\text { Country } \\
\text { group }\end{array}$ & $\begin{array}{c}\text { Number of } \\
\text { medals }\end{array}$ & Mean: $m$ & $\begin{array}{l}\text { Coefficient of } \\
\text { variation: } \mathrm{s} / \mathrm{m}\end{array}$ & $\begin{array}{c}\text { Number of } \\
\text { countries }\end{array}$ & $\begin{array}{l}\text { Countries } \\
\text { with } M>0\end{array}$ \\
\hline \multirow[t]{4}{*}{1964} & POL & 60 & 8.57 & 1.06 & 7 & 5 \\
\hline & $\mathrm{HIGH}$ & 39 & 2.79 & 1,47 & 14 & 6 \\
\hline & MIDDLE & 4 & 0.31 & 2.03 & 13 & 3 \\
\hline & LOW & 0 & 0.00 & 0.00 & 2 & 0 \\
\hline \multirow[t]{4}{*}{1968} & POL & 43 & 6.14 & 0.94 & 7 & 5 \\
\hline & $\mathrm{HIGH}$ & 53 & 3.53 & 1.08 & 15 & 8 \\
\hline & MIDDLE & 10 & 0.83 & 3.12 & 12 & 2 \\
\hline & LOW & 0 & 0.00 & 0.00 & 3 & 0 \\
\hline \multirow[t]{4}{*}{1972} & POL & 38 & 6.33 & 1.00 & 6 & 5 \\
\hline & $\mathrm{HIGH}$ & 58 & 4.46 & 0.93 & 13 & 11 \\
\hline & MIDDLE & 9 & 0.64 & 3.77 & 14 & 1 \\
\hline & LOW & 0 & 0.00 & 0.00 & 2 & 0 \\
\hline \multirow[t]{4}{*}{1976} & POL & 46 & 6.57 & 1.44 & 7 & 5 \\
\hline & $\mathrm{HIGH}$ & 58 & 4.14 & 1.35 & 14 & 9 \\
\hline & MIDDLE & 7 & 0.47 & 3.30 & 15 & 2 \\
\hline & LOW & 0 & 0.00 & 0.00 & 1 & 0 \\
\hline \multirow[t]{4}{*}{1980} & POL & 47 & 5.88 & 1.30 & 8 & 5 \\
\hline & $\mathrm{HIGH}$ & 61 & 4.69 & 1.39 & 13 & 10 \\
\hline & MIDDLE & 7 & 0.50 & 2.18 & 14 & 4 \\
\hline & LOW & 0 & 0.00 & 0.00 & 2 & 0 \\
\hline \multirow[t]{4}{*}{1984} & POL & 59 & 7.38 & 1.17 & 8 & 5 \\
\hline & $\mathrm{HIGH}$ & 57 & 4.07 & 1.53 & 14 & 11 \\
\hline & MIDDLE & 1 & 0.05 & 4.60 & 19 & 1 \\
\hline & LOW & 0 & 0.00 & 0.00 & 7 & 0 \\
\hline \multirow[t]{4}{*}{1988} & POL & 52 & 6.50 & 1.47 & 8 & 5 \\
\hline & $\mathrm{HIGH}$ & 79 & 5.27 & 1.32 & 15 & 11 \\
\hline & MIDDLE & 7 & 0.33 & 4.64 & 21 & 1 \\
\hline & LOW & 0 & 0.00 & 0.00 & 13 & 0 \\
\hline \multirow[t]{4}{*}{1992} & POL & 61 & 5.55 & 1.51 & 11 & 5 \\
\hline & $\mathrm{HIGH}$ & 95 & 6.33 & 1.32 & 15 & 9 \\
\hline & MIDDLE & 15 & 0.68 & 1.94 & 22 & 6 \\
\hline & LOW & 0 & 0.00 & 0.00 & 15 & 0 \\
\hline \multirow[t]{4}{*}{1994} & POL & 73 & 6.08 & 1.55 & 12 & 6 \\
\hline & $\mathrm{HIGH}$ & 88 & 5.18 & 1.46 & 17 & 8 \\
\hline & MIDDLE & 18 & 0.72 & 2.14 & 25 & 6 \\
\hline & LOW & 4 & 0.31 & 2.74 & 13 & 2 \\
\hline \multirow[t]{4}{*}{1998} & POL & 75 & 6.25 & 1.42 & 12 & 6 \\
\hline & $\mathrm{HIGH}$ & 98 & 5.44 & 1.47 & 18 & 9 \\
\hline & MIDDLE & 30 & 1.03 & 2.56 & 29 & 8 \\
\hline & LOW & 2 & 0.15 & 3.67 & 13 & 1 \\
\hline 2002 & POL & 73 & 5.62 & 1.44 & 13 & 7 \\
\hline \multicolumn{3}{|c|}{ Papeles de Europa } & & & & 65 \\
\hline
\end{tabular}

25 (2012): 51-75

Doi: http://dx.doi.org/10.5209/rev_PADE.2012.n25.41095 
Andreff, Wladimir. Is hosting the games enough to win? A predictive economic model of medal wins at 2014 winter olympics.

\begin{tabular}{|clccccc|} 
& HIGH & 134 & 7.05 & 1.58 & 19 & 11 \\
& MIDDLE & 27 & 0.96 & 2.33 & 28 & 6 \\
& LOW & 0 & 0.00 & 0.00 & 17 & 0 \\
& POL & 93 & 7.15 & 1.30 & 13 & 8 \\
& HIGH & 122 & 6.78 & 1.43 & 18 & 11 \\
& MIDDLE & 37 & 1.12 & 2.70 & 33 & 7 \\
& LOW & 0 & 0.00 & 0.00 & 16 & 0 \\
2010 & POL & 86 & 6.62 & 1.39 & 13 & 12 \\
& HIGH & 134 & 7.05 & 1.47 & 19 & 5 \\
& MIDDLE & 37 & 1.12 & 2.95 & 33 & 1 \\
\hline
\end{tabular}

s: standard deviation; M: number of medals per country

The distribution of medal wins across these four country groups from the 1964 to 2010 Winter Olympics (Table 6) suggests that snow coverage might well be a significant determinant of medal wins in winter sports. Countries with high snow coverage followed by countries with polar-like climate and snow coverage concentrate the great bulk of medal wins at Winter Olympics. The number of countries with high snow coverage increased from 14 in 1964 up to 19 in 2010 while their number of medals won grew from 39 to 134. During the same span of time, the number of countries with polar-like snow coverage augmented from 7 in 1964 to 13 in 2010 whereas their number of medal wins increased from 60 to 86 . On the other hand, 13 countries with middle snow coverage had won only 4 medals in 1964; they were 33 participating at the 2010 Games where they won 37 medals. With regards to countries with low (or no) snow coverage, the marked increase in their participation (from 2 to 17) did not translate into an impressive growth in medal wins (from 0 to 1 with once 4 medals won in 1994 and once 2 medals in 2002). Snow coverage seems to be a differentiating factor among countries participating to Winter Olympics.

A second new variable is introduced in the model to capture each country's endowment with winter sports resorts and facilities. Here we have relied on data available on various web sites describing ski resorts in different countries in the world, namely www.skiinfo.fr, www.sports-hiver.com, www.neigeski.com, www.levoyageur.net/stations, www.fr.snow-forecast.com, www.french-china.org. A RESORT dummy variable has been designed on the basis of such information, considering a country as being endowed with many ski resorts and winter sports facilities when it has over 60 of them at its disposal. A country with a number of skiing resorts between 5 and 60 is considered as having an average endowment by world standard. A country with a number of ski resorts and winter sports facilities below 5 is assessed and ranked as having few opportunities to win medals due to her short availability of resorts-facilities. The three country groups are comprised of:

- MANY winter sports resorts: Austria, Canada, Czechoslovakia, France, Germany (GDR), Italy, Japan, Norway, Russia (CIS, USSR), Sweden, Switzerland, USA = 12 countries;

- BETWEEN many and few winter sports resorts: Australia, Belgium, Bulgaria, Chile, China, Croatia, Czech Republic, Finland, Iran, Kyrgyzstan, Lebanon, Netherlands, New Zealand, Poland, Romania, Slovakia, Slovenia, South Korea, Spain, Turkey, Ukraine (Yugoslavia) = 21 countries; 
Andreff, Wladimir. Is hosting the games enough to win? A predictive economic model of medal wins at 2014 winter olympics.

- FEW/NO winter sports resorts: Albania, Algeria, American Samoa, Argentina, Armenia, Azerbaijan, Belarus, Bermuda, Bolivia, Bosnia-Herzegovina, Brazil, Cameroon, Colombia, Costa Rica, Cyprus, Denmark, Ethiopia, Estonia, Fiji, Georgia, Great Britain, Ghana, Greece, Guam, Guatemala, Honduras, Hungary, Iceland, India, Ireland, Israel, Jamaica, Kazakhstan, Kenya, Latvia, Lithuania, Luxembourg, Macedonia, Madagascar, Mexico, Moldova, Mongolia, Morocco, Nepal, Netherlands Antilles, North Korea, Pakistan, Philippines, Portugal, Peru, Senegal, Serbia, South Africa, Swaziland, Thailand, Taiwan, Tajikistan, Trinidad \& Tobago, Uruguay, Uzbekistan, Venezuela, Virgin Islands $=62$ countries.

Table 7 - Medal distribution and winter sports resorts and winter sports facilities

\begin{tabular}{|c|c|c|c|c|c|c|}
\hline Year & $\begin{array}{l}\text { Country } \\
\text { group }\end{array}$ & $\begin{array}{c}\text { Number of } \\
\text { medals }\end{array}$ & Mean: m & $\begin{array}{l}\text { Coefficient of } \\
\text { variation: } \mathrm{s} / \mathrm{m}\end{array}$ & $\begin{array}{c}\text { Number of } \\
\text { countries }\end{array}$ & $\begin{array}{l}\text { Countries } \\
\text { with } M>0\end{array}$ \\
\hline \multirow[t]{3}{*}{1964} & MANY & 89 & 7.42 & 0.97 & 12 & 10 \\
\hline & BETWEEN & 13 & 0.87 & 2.98 & 15 & 3 \\
\hline & FEW / NO & 1 & 0.11 & 3.00 & 9 & 1 \\
\hline \multirow[t]{3}{*}{1968} & MANY & 91 & 7.00 & 0.57 & 13 & 12 \\
\hline & BETWEEN & 15 & 1.00 & 2.56 & 15 & 3 \\
\hline & FEW / NO & 0 & 0.00 & 0.00 & 9 & 0 \\
\hline \multirow[t]{3}{*}{1972} & MANY & 89 & 6.85 & 0.69 & 13 & 13 \\
\hline & BETWEEN & 16 & 1.14 & 2.31 & 14 & 4 \\
\hline & FEW / NO & 0 & 0.00 & 0.00 & 8 & 0 \\
\hline \multirow[t]{3}{*}{1976} & MANY & 95 & 6.79 & 1.15 & 14 & 12 \\
\hline & BETWEEN & 15 & 0.94 & 2.38 & 16 & 3 \\
\hline & FEW / NO & 1 & 0.14 & 2.71 & 7 & 1 \\
\hline \multirow[t]{3}{*}{1980} & MANY & 95 & 6.79 & 1.11 & 14 & 13 \\
\hline & BETWEEN & 18 & 1.28 & 2.06 & 14 & 4 \\
\hline & FEW / NO & 2 & 0.22 & 2.00 & 9 & 2 \\
\hline \multirow[t]{3}{*}{1984} & MANY & 100 & 7.14 & 1.10 & 14 & 13 \\
\hline & BETWEEN & 16 & 1.00 & 3.25 & 16 & 3 \\
\hline & FEW / NO & 1 & 0.56 & 0.43 & 18 & 1 \\
\hline \multirow[t]{3}{*}{1988} & MANY & 120 & 8.57 & 1.02 & 14 & 13 \\
\hline & BETWEEN & 18 & 1.13 & 2.14 & 16 & 4 \\
\hline & FEW / NO & 0 & 0.00 & 0.00 & 27 & 0 \\
\hline \multirow[t]{3}{*}{1992} & MANY & 148 & 11.38 & 0.76 & 13 & 12 \\
\hline & BETWEEN & 20 & 1.18 & 1.75 & 17 & 6 \\
\hline & FEW / NO & 3 & 0.09 & 4.22 & 33 & 2 \\
\hline \multirow[t]{3}{*}{1994} & MANY & 150 & 12.5 & 0.71 & 12 & 11 \\
\hline & BETWEEN & 25 & 1.25 & 1.64 & 20 & 7 \\
\hline & FEW / NO & 8 & 0.23 & 3.00 & 35 & 4 \\
\hline \multirow[t]{3}{*}{1998} & MANY & 155 & 12.92 & 0.66 & 12 & 11 \\
\hline & BETWEEN & 44 & 2.00 & 1.86 & 22 & 9 \\
\hline & FEW / NO & 6 & 0.16 & 3.06 & 38 & 4 \\
\hline \multirow[t]{2}{*}{2002} & MANY & 186 & 15.5 & 0.73 & 12 & 11 \\
\hline & BETWEEN & 42 & 1.83 & 1.47 & 23 & 10 \\
\hline
\end{tabular}

Papeles de Europa 
Andreff, Wladimir. Is hosting the games enough to win? A predictive economic model of medal wins at 2014 winter olympics.

\begin{tabular}{|llccccc|} 
& FEW / NO & 6 & 0.14 & 4.07 & 42 & 3 \\
2006 & MANY & 191 & 15.92 & 0.59 & 12 & 11 \\
& BETWEEN & 55 & 2.50 & 1.52 & 22 & 11 \\
& FEW / NO & 6 & 0.13 & 3.85 & 46 & 4 \\
2010 & MANY & 188 & 15.67 & 0.72 & 12 & 11 \\
& BETWEEN & 62 & 2.82 & 1.43 & 22 & 10 \\
& FEW / NO & 8 & 0.17 & 3.29 & 48 & 5 \\
\hline
\end{tabular}

s: standard deviation; M: number of medals per country

Countries with a good endowment in ski resorts and winter sports facilities are winning an increasing number of Olympic medals from 89 in 1964 to 188 in 2010 (even 191 in 2006) while their number has always stood between 12 and 14 (Table 7). The number of participating countries with few or no resorts-facilities has grown from 9 in 1964 to 48 in 2010 whereas their number of medal wins has increased from 1 to 8 . The number of countries with an average endowment stands in between as to their medal wins. It seems that a shortage of ski resorts and winter sports facilities is a hindrance to win medals at Winter Olympics whereas medal wins benefit to wellendowed countries.

Thus, the model is adapted to estimating the determinants of medal wins at Winter Olympics as follows:

$$
\begin{aligned}
M_{i, t}^{*}=c+ & \alpha \ln N_{i, t-4}+\beta \ln \left(\frac{Y}{N}\right)_{i, t-4}+\gamma \text { Host }_{i, t}+\sum_{p} \delta_{p} \text { Political Regime }_{p, i} \\
& +\sum_{r} \rho_{r} \text { Snow }_{r}+\sum_{l} \lambda_{l} \text { Resort }_{l}+\varepsilon_{i, t}
\end{aligned}
$$

where $\varepsilon_{i, t} \sim N\left(0, \sigma_{\varepsilon}^{2}\right)$

$M_{i, t}$ observation is defined by $M_{i, t}=\left\{\begin{array}{ccc}M_{i, t}^{*} & \text { si } & M_{i, t}^{*}>0 \\ 0 & \text { si } & M_{i, t}^{*} \leq 0\end{array}\right.$

and $N$ is the population of a nation, $Y / N$ is its GDP per inhabitant, both variables being four-year lagged for the same reason as with Summer Olympics, Host is a dummy variable identifying the country that hosts the Games, Political Regime is a dummy variable which captures the impact of the political regime on medal wins, Snow is a dummy variable differentiating countries with regards to their degree of annual snow coverage, and Resort is a dummy capturing the significance of ski resorts and winter sports facilities located in a country.

\section{ECONOMIC DETERMINANTS OF MEDAL WIN AT WINTER OLYMPIC GAMES}

Model (4) is now used for estimating whether the above-listed variables are significant determinants of medal wins at Winter Olympics. Econometric testing covers all Winter Olympics from 1964 up to 2010. Data for population and GDP per inhabitant are taken from CHELEM data base (which retrieves and proceeds to consistency checks between World Bank and OECD data). A first specification M1 
Andreff, Wladimir. Is hosting the games enough to win? A predictive economic model of medal wins at 2014 winter olympics.

resorts to a left-hand censored Tobit model since a non negligible number of countries that participate to Winter Olympics do not win any medal. Therefore, a zero value of the $M_{i, t}$ dependent variable does not mean that a country has not participated and we work out a simple Tobit, not a Tobit 2 (with a two stage Heckman procedure). This first specification takes on board five explanatory variables: population, GDP per inhabitant, the three dummies Host, Snow and Resort. The MIDDLE country group which contains the biggest number of countries is taken as the reference for the Snow dummy. With the same rationale, the most numerous FEW/NO country group is taken as the reference for the Resort dummy. In a second specification M2, the censored Tobit model includes in addition the Political Regime dummy variable. A third specification $\mathrm{M} 3$ is the one which will be used later on for prediction and it encompasses one more explanatory variable, i.e. the inertial variable $M_{i, t-4 \text {. }}$

Table 8 - Tobit estimations of medals won at Winter Olympics

\begin{tabular}{|c|c|c|c|}
\hline Independent variables & Tobit model M1 & Tobit model M2 & Tobit model M3 \\
\hline Log population (t-4) & $2.006 * * *$ & $1.873^{* * *}$ & $0.787^{* * *}$ \\
\hline Log GDP per inhabitant (t-4) & $3.732^{* \star *}$ & $6.958^{* * *}$ & $2.813^{* * *}$ \\
\hline Host & 2.732 & $3.245^{*}$ & $3.874^{* * *}$ \\
\hline \multicolumn{4}{|l|}{ Resort (ref. FEW/NO) } \\
\hline MANY & 13.596 *** & $15.633^{* * *}$ & 5.904 *** \\
\hline BETWEEN & $5.889 * \star \star$ & $6.951^{\star * *}$ & $2.989^{* \star *}$ \\
\hline \multicolumn{4}{|l|}{ Snow (ref. MIDDLE) } \\
\hline POLAR & $8.042^{* * *}$ & $5.390 * * *$ & $2.092^{* *}$ \\
\hline $\mathrm{HIGH}$ & 0.922 & -1.292 & -0.286 \\
\hline LOW & -1.906 & -0.313 & -0.653 \\
\hline \multicolumn{4}{|l|}{ Political regime (ref. CAPME) } \\
\hline CEEC & & $6.302 * * *$ & $3.186^{* * *}$ \\
\hline EXCOM & & $10.077^{* * *}$ & 3.839 *** \\
\hline Medals (t-4) & & & $0.828^{* * *}$ \\
\hline Constant & $-24.198 * * *$ & $-34.252^{* * *}$ & -15.733 \\
\hline Number of observations & 663 & 663 & 662 \\
\hline Log-likelihood value & -957.881 & -928.749 & -811.892 \\
\hline Pseudo-R2 & 0.221 & 0.245 & 0.339 \\
\hline
\end{tabular}

In all three specifications (Table 8), GDP per inhabitant and population are very significant determinants of medal wins at Winter Olympics with a positive sign. Medals are basically shared across developed economies with rather important population. More interesting is that the endowment in ski and winter sports resorts is also a very significant determinant of medal wins. Belonging to the BETWEEN country group significantly increases a nation's probability to win medals at Winter Olympics and it is even more so for those countries with many winter sports resorts. The very existence of winter sports resorts reflects a high capacity of having a winter sports practice in a country and, consequently, selecting experienced athletes in the national squad. 
Andreff, Wladimir. Is hosting the games enough to win? A predictive economic model of medal wins at 2014 winter olympics.

Snow coverage surprisingly does not appear as a significant determinant of Winter Olympics medal wins. Compared with MIDDLE coverage country group, polar-like countries have a significant probability to win more medals, but this probability is not significant for high snow coverage countries; the probability to win fewer medals is not significant for low snow coverage countries. The same result shows up with the other two specifications M2 and M3. Indeed, some countries with high snow coverage do not perform that well at Winter Olympic Games such as Tajikistan and Kyrgyzstan. It is not enough for a country to have snow, if it does not have enough ski resorts and winter sports facilities to train potential medal winners at Winter Games.

Introducing a Political regime dummy in our second specification improves the estimation overall (Pseudo-R2 increases). The host country dummy becomes significant (though at 10\%). Being a Central and Eastern European post-communist nation increases its probability to win medals at Winter Olympics and it is even more so for the EXCOM country group (CIS countries and all other non Soviet former communist countries).

The third specification $\mathrm{M} 3$ is by far the best one with a marked improvement of the Pseudo-R2. Moreover all explanatory variables are significant except snow coverage with regards to high and low snow coverage countries. The inertial variable - medal wins at previous Winter Olympics - is significant as well and the host country dummy becomes significant at $1 \%{ }^{12}$. This model fits well for predicting medal wins at the Sochi Winter Games.

\section{ECONOMIC PREDICTION OF MEDAL WINS AT THE 2014 SOCHI WINTER OLYMPICS}

Our prediction exercise based on model M3 takes CHELEM preliminary data for 2010 as regards to population and GDP per inhabitant and then calculates the Sochi outcome in terms of medal wins (Table 9). The expected winner (first ranked country) is the U.S. with 36 medal wins, just like it has been in Vancouver 2010 with 37 medals. Germany ranks second with 28 medal wins while she has ranked first in 2006 (29 medals), 2002 (36 medals), 1998 (29 medals), 1992 (26 medals), and second in 2010 (30 medals). Canada takes over the third rank with 27 medals like in Vancouver 2010 (26 medals) and Turin 2006 (24 medals). France is expected to win 12 medals in Sochi ( $8^{\text {th }}$ rank) as against 11 in Vancouver, 9 in Turin, 11 in Salt Lake City, 8 in Nagano, 5 in Lillehammer, 9 in Albertville 1992 and ... 9 in Grenoble 1968 (with a strong host country effect).

Winning 24 medals, Russia would rank fourth at Sochi Games. It is not enough to host Winter Games to be the winner. However, it would be a quite better performance than the disastrous 15 medals won in Vancouver $\left(6^{\text {th }}\right.$ rank behind Norway and Austria) and 13 medals in Salt Lake City (6 ${ }^{\text {th }}$ rank). Sochi Olympics might materialise the end of the deep transformation of the Russian sports system

\footnotetext{
12 We have also tested a fourth specification including the Regions dummy variable used in the Summer Olympics model. For three regions the test does not provide any result since these regions have never won a medal at Winter Games. For most other regions, the variable is not significant even at a $10 \%$ threshold.
}

Papeles de Europa

25 (2012): 51-75 
Andreff, Wladimir. Is hosting the games enough to win? A predictive economic model of medal wins at 2014 winter olympics.

undertaken during the 1990s and 2000s. This would be a sign of Russian recovery as a Winter Olympics sporting power but without coming back to the 1976-1988 "golden age" when the Soviet squad usually was winning between one fifth and one quarter of all distributed medals. Economic (and sporting system's) transformation was a shock on Russian and CIS medal wins, whose share fell below $10 \%$ of medals total since 2002. In particular, the transformational recession (Kornaï, 1994) has seriously affected Russia's GDP per capita downwards until 1998; the same roughly applies to other CIS countries. In our model, a decreasing GDP per capita explains a lower number of medal wins. A decreasing number of medals for Russia is (only partly) compensated by the emergence of Belarus, Kazakhstan and Ukraine as more or less regular medal winners at Winter Games since 1994 (Table 10). However the confidence interval for Russian medal wins is between 21 and 27 (Table 9). So that, in the worst case, Russia may win less medals in 2014 than at the 1994 and 2006 Winter Games, which would not seem to be very rewarding as considered by Russian sports authorities. Moreover, our model predicts no medal win for Kazakhstan and Ukraine in Sochi 2014 and only one for Belarus.

Table 9 - Prediction of medal wins at Sochi Winter Olympics

\begin{tabular}{|l|cccc|}
\hline Countries & $\begin{array}{c}\text { Medals won } \\
\text { in } 2010\end{array}$ & $\begin{array}{c}\text { Medal wins } \\
\text { predicted in 2014 }\end{array}$ & Lower bound & Upper bound \\
\hline USA & 37 & 36 & 33 & 38 \\
Germany & 30 & 28 & 26 & 30 \\
Canada & 26 & 27 & 25 & 28 \\
Russia & 15 & 24 & 21 & 27 \\
Norway & 23 & 24 & 22 & 25 \\
Austria & 16 & 15 & 14 & 16 \\
Sweden & 11 & 13 & 12 & 14 \\
France & 11 & 12 & 11 & 13 \\
China & 11 & 11 & 9 & 13 \\
South Korea & 14 & 11 & 10 & 13 \\
Switzerland & 9 & 9 & 8 & 10 \\
Japan & 5 & 7 & 6 & 9 \\
Italy & 5 & 7 & 6 & 8 \\
Netherlands & 8 & 6 & 5 & 7 \\
Poland & 6 & 6 & 4 & 8 \\
Czech Republic & 6 & 6 & 4 & 7 \\
Finland & 5 & 5 & 3 & 6 \\
Australia & 3 & 3 & 1 & 4 \\
Slovenia & 3 & 2 & 1 & 4 \\
Croatia & 3 & 2 & 0 & 3 \\
Slovakia & 3 & 1 & 0 & 3 \\
Belarus & 3 & & & 4 \\
\hline
\end{tabular}


Andreff, Wladimir. Is hosting the games enough to win? A predictive economic model of medal wins at 2014 winter olympics.

Table 10 - Medal wins by (post)-communist countries, 1964-2010

\begin{tabular}{|c|c|c|c|c|c|c|c|c|c|c|c|c|c|}
\hline Country & 1964 & 1968 & 1972 & 1976 & 1980 & 1984 & 1988 & 1992 & 1994 & 1998 & 2002 & 2006 & 2010 \\
\hline \multicolumn{14}{|l|}{ CEECs } \\
\hline Bulgaria & & & & & 1 & & & & & 1 & 3 & 1 & \\
\hline Czech Republic & & & & & & & & & & 3 & 3 & 4 & 6 \\
\hline Estonia & & & & & & & & & & & 3 & 3 & 1 \\
\hline Hungary & & & & & 1 & & & & & & & & \\
\hline Latvia & & & & & & & & & & & & 1 & 2 \\
\hline Poland & & & 1 & & & & & & & & 2 & 2 & 6 \\
\hline Romania & & 1 & & & & & & & & & & & \\
\hline Slovakia & & & & & & & & & & & & 1 & 3 \\
\hline Slovenia & & & & & & & & & 3 & & 1 & & 3 \\
\hline former Czechoslovakia & 1 & 4 & 3 & 1 & 1 & 6 & 3 & 3 & & & & & \\
\hline former GDR & & 5 & 14 & 19 & 23 & 24 & 25 & & & & & & \\
\hline former Yugoslavia & & & & & & 1 & 3 & & & & & & \\
\hline CEECs/medias total \% & 1.0 & 9.4 & 17.1 & 18.0 & 22.7 & 26.5 & 22.5 & 1.7 & 1.6 & 1.9 & 5.4 & 4.8 & 8.1 \\
\hline \multicolumn{14}{|l|}{ CIS countries } \\
\hline Belarus & & & & & & & & & 2 & 2 & 1 & 1 & 3 \\
\hline Kazakhstan & & & & & & & & & 3 & 2 & & & 1 \\
\hline Russia & & & & & & & & & 23 & 18 & 13 & 22 & 15 \\
\hline Ukraine & & & & & & & & & 2 & 1 & & 2 & \\
\hline Uzbekistan & & & & & & & & & 1 & & & & \\
\hline former USSR & 25 & 13 & 16 & 27 & 22 & 25 & 29 & $23^{*}$ & & & & & \\
\hline CIS/medals total (\%) & 24.3 & 12.3 & 15.2 & 24.3 & 19.1 & 21.4 & 21.0 & 13.4 & 16.9 & 11.2 & 6.0 & 9.9 & 7.4 \\
\hline \multicolumn{14}{|l|}{ Other EXCOM } \\
\hline China & & & & & & & & 3 & 3 & 8 & 8 & 11 & 11 \\
\hline Croatia & & & & & & & & & & & 4 & 3 & 3 \\
\hline North Korea & & & & & & & & 1 & & & & & \\
\hline
\end{tabular}

CIS unified squad.

With regards to CEECs, the transition economic shock was slightly milder than in CIS countries and transformational recession lasted shorter. Nevertheless, transition has triggered a dramatic drop in CEEC medal wins at Winter Games which fell down to 3 Czechoslovak medals in 1992, 3 Slovene medals in 1994, 1 Bulgarian and 3 Czech medals in 1998. The recovery in medal wins has been quite slower than economic recovery since the sports sector was not a top priority in the transition strategy backed by Washington organisations (IMF and the World Bank). Moreover medal wins are scattered across eight CEECs since 2002, except Hungary and Lithuania. The most spectacular shock on medal wins in CEECs derives from German unification in 1990. The former GDR also enjoyed a sort of "golden age" from 1972 to 1988 with between 14 and 25 medal wins at Winter Olympics ${ }^{13}$. At the 1992 Winter Games, the unified German squad, taking stake of East German athletes, outperformed (with 26 medals) all other participating countries including the CIS

\footnotetext{
${ }^{13}$ We do not come back here to specific determinants of Olympics performances reached by the communist GDR, see Andreff et al. (2008) and Dryden (2006). 
Andreff, Wladimir. Is hosting the games enough to win? A predictive economic model of medal wins at 2014 winter olympics.

unified squad (23 medals). Since then Germany has become the top performer at Winter Olympics with the biggest number of medals won from Albertville 1992 to Vancouver 2010 (except Lillehammer 1994, $2^{\text {nd }}$ rank behind Norway).

In Sochi 2014, our model forecasts only 16 medal wins for CEECs taken altogether, which would be a step back compared to the 2010 recovery with 21 medals though better than 12 medal wins in 2002 and 2006. This would merely benefit to the Czech and Polish squads, 6 medals each, then to Slovenia and Slovakia (2 medals each). Estonia, Latvia and Bulgaria, which had been able to win medals in the four previous Games, are not expected to win any of them at Sochi Winter Olympics.

A final note about other post-communist countries must underline the rise of China as a new Winter Olympics winner (ranked $11^{\text {th }}$ in $1998,10^{\text {th }}$ in $2002,9^{\text {th }}$ in 2006 and $8^{\text {th }}$ in 2010), even though this cannot compare with this nation's outstanding performance at the Summer Games hosted in Beijing. Thus, it is not surprising that our model predicts again 11 medal wins for China in 2014 ( $9^{\text {th }}$ rank) but note that the upper bound of the interval confidence for China is 13 medals. If the Chinese squad performs very well, it may even pretend to the $7^{\text {th }}$ rank in terms of medal wins at Sochi Games. Croatia did extremely well - given the size (population, GDP) of this country - since the 2002 Winter Games. The model forecasts 2 Croatian medals in Sochi, with an upper bound at 4 medals, like at the 2002 Winter Olympics.

\section{CONCLUSION: ECONOMIC PREDICTION AND SURPRISING SPORT OUTCOMES}

All the above predictions must be taken with a pinch of salt. This is namely due to a number of surprising sporting outcomes. Indeed, there are many unexpected sporting outcomes observed ex post - i.e. achieved outcomes markedly different from the forecast - even though it happens more with the FIFA World Cup than Summer Olympics (M. \& W. Andreff, 2010). Unexpected or surprising outcomes of a sport contest have not really been analysed so far. This happens when opponents in a sport contest have clearly uneven sporting forces, and the underdog wins the favourite. Elaborating on a metrics to quantify surprising sporting outcomes should be a promising avenue for further research. It will be possible to check after Sochi 2014 whether Winter Olympics are characterised with many or few surprising sport outcomes.

With regards to the host country, Russia is not likely to win the biggest number of medals at Sochi Winter Games. If she makes it with more than 27 medals one would be allowed to conclude that she performed very well, better than expected with an economic model, and that this must be due to exceptional efforts of Russian athletes and coaches before and during Sochi Games. If Russia would win less than 21 medals, you could join Prime Minister Medvedev and President Putin in complaining that the Russian winter sports squad should really have done better - or that it was unexpectedly bad lucky. 
Andreff, Wladimir. Is hosting the games enough to win? A predictive economic model of medal wins at 2014 winter olympics.

\section{REFERENCES}

Andreff M., W. Andreff \& S. Poupaux (2008), Les déterminants économiques de la performance olympique: Prévision des médailles qui seront gagnées aux Jeux de Pékin, Revue d'Economie Politique, 118 (2), 135-69.

Andreff W. (2001), The Correlation between Economic Underdevelopment and Sport, European Sport Management Quarterly, 1 (4), 251-79.

Andreff W. (2004), Would a Second Transition Stage Prolong the Initial Period of Post-socialist Economic Transformation into Market Capitalism?, European Journal of Comparative Economics, 1 (1), 7-31.

Andreff W. (2007), Economie de la transition: La transformation des économies planifiées en économies de marché, Paris: Bréal.

Andreff W. (2009), Comparaison entre les prévisions et les médailles gagnées aux Jeux de Pékin, in INSEP, Pékin 2008: Regards croisés sur la performance sportive olympique et paralympique, INSEP, Secrétariat d'Etat aux Sports, Paris, 241-47.

Andreff W. (2010), Economic modeling and prediction of Summer Olympic medal wins and FIFA World Cup semi-finalists, Conference Economie, politique et société: nouveaux défis et perspectives, Higher School of Economics, Moscow, October 28-29.

Arellano M. \& S. Bond (1991), Some Tests of Specification for Panel Data: Monte Carlo Evidence and an Application to Employment Equations, Review of Economic Studies, 58, 277-97.

Ball (1972), Olympic Games Competition: Structural Correlates of National Success, International Journal of Comparative Sociology, 13, 186-200.

Bernard A.B. (2008), Going for the Gold: Who Will Win the 2008 Olympic Games in Beijing,

http://mba.tuck.dartmouth.edu/pages/faculty/andrew.bernard/Beijing2008.

Bernard A.B. \& M.R. Busse (2004), Who Wins the Olympic Games: Economic Resources and Medal Totals, Review of Economics and Statistics, 86 (1), 41317.

Clarke (2000), ), Home Advantage in the Olympic Games, in G. Cohen \& T. Langtry, eds., Proceedings of the Fifth Australian Conference on Mathematics and Computers in Sport, Conference proceedings, Sydney: University of Technology Sydney, 43-51.

Dryden N. (2006), «For Power and Glory: State-Sponsored Doping and Athletes' Human Rights», Sports Lawyers Journal, 13 (1), 1-40.

Forrest D., A. Ceballos, R. Flores, I.G. McHale, I. Sanz \& J.D. Tena, Explaining and Forecasting National Team Medals Totals at the Summer Olympic Games, in: W. Maennig \& A. Zimbalist, eds., International Handbook on the Economics of Mega Sporting Events, Edward Elgar, Cheltenham 2012, 208-24.

Grimes A.R., W.J. Kelly \& P.H. Rubin (1974), A Socioeconomic Model of National Olympic Performance, Social Science Quarterly, 55, 777-82.

Hawksworth J. (2008), Economic Briefing Paper: Modeling Olympic Performance, PricewaterhouseCoopers, June.

Hoffmann R., L.Chew Ging \& B. Ramasamy (2002), Public Policy and Olympic Success, Applied Economic Letters, 9, 545-48.

Jiang M. \& L.C. Xu (2005), Medals in Transition: Explaining Medal Performance and Inequality of Chinese Provinces, Journal of Comparative Economics, 33 (1), 158-72. 
Andreff, Wladimir. Is hosting the games enough to win? A predictive economic model of medal wins at 2014 winter olympics.

Johnson D. \& A. Ali (2004), A Tale of Two Seasons: Participation and Medal Counts at the Summer and Winter Olympic Games, Social Science Quarterly, 85 (4), 974-93.

Johnson D. \& A. Ali (2008). Predictions for Medal Counts at Beijing Olympics, Based on Economic Model:

http://faculty1.coloradocollege.edu/ djohnson/Olympics/Beijing2008predictions. pdf

Kornaï J. (1994), 'Transformational' recession. The main causes, Journal of Comparative Economics, 19 (1).

Levine N. (1974), Why Do Countries Win Olympic Medals? Some Structural Correlates of Olympic Games Success: 1972, Sociology and Social Research, 58, 353-60.

Maennig W. \& Wellebrock C., (2008), Sozioökonomische Schätzungen olympischer Medaillen-gewinne. Analyse-, Prognose- und Benchmarkmöglichkeiten. Sportwissenschaft 2, 131-48.

Nevill A., G. Atkinson, M. Hughes \& S. Cooper (2002), Statistical Methods for Analyzing Discrete and Categorial Data Recorded in Performance Analysis, Journal of Sports Sciences, 20 (10), 829-44.

Novikov A.D. \& A.M. Maximenko (1972), The Influence of Selected Socio-economic Factors on the Levels of Sports Achievements in the Various Countries, International Review of Sport Sociology, 7, 27-44.

Pfau W.D. (2006), Predicting the Medal Wins by Country at the 2006 Winter Olympic Games: An Econometric Approach, National Graduate Institute for Policy Studies, Tokyo, January, mimeo.

Poupaux S. \& W. Andreff (2007), The Institutional Dimension of the Sports Economy in Transition Countries, in M.M. Parent \& T. Slack, eds., International Perspectives on the Management of Sport, Amsterdam: Elsevier, 99-124.

Rathke A. \& U. Woitek (2008), Economics and the Summer Olympics: An Efficiency Analysis, Journal of Sports Economics, 9 (5), 520-37.

Wang J. \& Y. Jiang (2008), Logarithm Model Prediction for 2008 Beijing Olympic Games, International Journal of Sports Science and Engineering, 2 (1), 47-51. 